\title{
Digitization: Does It Always Improve Access to Rare Books and Special Collections?
}

\author{
Dale J. Correa \\ The University of Texas at Austin
}

\begin{abstract}
In April 2016, the Israel State Archives announced the most recent stage of an ambitious project to digitize all of their holdings (potentially 400 million pages of material): the new archival website was ready online. 1 With the new website came the ability to request digital copies of documents, which would be available on the website within two weeks of the request. 2 However, researchers would now at the very least be discouraged from requesting access to the paper documents, 3 or, in the worst-case scenario, be refused access to anything except the website. 4 Local scholars (including a prominent professor of history at Tel Aviv University), the Akevot Institute for Israeli-Palestinian Conflict Research, and the Middle East Studies Association of North America (which publishes the prestigious International Journal of Middle East Studies) registered concern with the restriction of physical access to the archive and issued public calls for a reversal of the decision. 5 The conflict was between perceived best practices of digitization and of archival stewardship (represented by the State Archivist Dr. Yaacov Lozowick) on the one hand, and standards and expectations for scholarly research on the Middle East, which largely depends on archival and rare book collections, on the other.
\end{abstract}

The conflict among access, preservation, and scholarly research habits and expectations represented in the case of the Israel State Archives is not unique. Any time a special collections holdings-physical access is lost (hopefully, temporarily), enhanced preservation is gained, digital access is born, and the scholarly research expectations of scholars attuned to the use of digital material are improved through access to digital surrogates. It is perhaps ironic that scholars in North America would complain about digital access to materials in Israel-is it not the ideal scenario that everything of research interest should end up freely available on the Internet? In this paper, I examine these positive and negative aspects of the digitization of rare books and special collections from the perspectives of preservation, access, and scholarly research methods. My conclusion is mixed, in that the benefits do not outweigh the disadvantages or risks, but neither are the risks so severe that rare book and special collections librarians should banish the thought of digitization altogether.

From the perspective of preservation, digitization is a blessing and a curse. Controlling the amount of human interaction that special materials have is a goal of established, restrictive access policies in the most welcoming of special collections libraries. Even when librarians want their collections to be known and appreciated, they must still contend with the realities of preservation. The same could be said to apply to digitization in the short term: digitization requires intensive human and machine handling of materials, and exposure to a number of conditions that librarians are most wary of. The National Szechenyi Library of Hungary 
encountered these issues when they considered digitizing part of their collection with an aim to increase access while lessening potential harm to the materials from continued patron use. 6 The National Szechenyi Library was particularly concerned about temperature, light exposure, weight imposed on materials in flipping folios, and distortion from perspective shortening in processing the scanned images. 7 They were able to compensate for these concerns in their selection of equipment and software-a DigiBook 6000 scanner-that also allowed them to capture highquality images showing "even the faintest stroke.” 8 The scanner exposed the manuscripts to conditions no worse than those of an exhibition, which the National Szechenyi Library determined to be a fair price for increasing access to their holdings.9 The importance of making their materials available beyond their restrictive security and preservation measures outweighed the preservation risks posed by digitization.

A second preservation-related issue is cost, and not simply the cost of digitization. Rather, the preservation of the digital surrogate demands the greatest cost in the form of "data administration and management." 10 The high costs associated with the long-term preservation of unstable and easily disintegrated digital surrogates produces a stratification effect much like that of the database market: "the research capabilities of any given institution are currently limited to those databases economically attainable for that institution, either singly or consortially." 11 And so it is with digitization: the digitization capabilities of an institution are limited to what it can afford. In the case of the National Szechenyi Library, they chose a sub-collection of manuscripts that could be digitized with the time and resources available.12 Unfortunately, this meant that they could produce only raw, high resolution images, with no online portal to make them widely available.13 That the files exist on CDs alone also calls into question whether or not this was a worthwhile "preservation" project. 14

The National Szechenyi Library was highly motivated to make their collections available to a wide audience, even if they did not quite reach their goal in the end. This may not be the case for all institutions; for example, the Israel State Archives may wish to use preservationthrough-digitization as an excuse to limit access to their originals.15 Furthermore, questions have been raised around the role of a military censor in determining which materials will be made available in the new online, digital archive. 16 At the least, materials are completely unavailable while undergoing digitization, which may produce inconvenient situations for traveling researchers who cross oceans to conduct research at the Israel State Archives.

In addition to realizing librarians' ideal commitment to the freedom of access to information, access issues are intimately tied up with scholarly research methods. A digital surrogate can provide the information conveyed in words or images, but it cannot capture the information contained in the physicality of special collections materials. An excellent example of the loss of not only physical information from special collections materials, but also intangible information from the printed word, is the immense gap in newspaper collecting throughout the United States that was caused by the existence of multiple editions, the move to microfilm, and eventually, the move to digitization.17 Richard Saunders has noted that collecting newspapers was a messy prospect even in the all-print era due to the number of editions for each newspaper.18 When digitization became fashionable, as well as extremely attractive to researchers who could perform full-text searches across a large date range, having digital copies streamlined research the same way that texts available in microfilm had done a generation previously.19 It is not feasible to digitize every edition of every newspaper; furthermore, librarians did not collect every edition of every historic newspaper due to edition confusion and selective collecting for microfilming projects. 20 Thus, newspaper collections have become 
available digitally, but only in their most limited and selective form in digital databases-limited in the selection of papers to scan, in the daily edition to select (morning, afternoon, evening), and in how much of the newspaper was converted to digital form (were pages of advertisements, or whole advertising sections, for instance, left out of the scanned copies?). Such selection actually yielded results opposite of what was intended by a technology meant to facilitate access and innovative research methods.

Ironically, the solution to this particular digitization dilemma may be print newspaper clipping morgues, of which few exist. The problem with the clipping morgues is that they do not represent the totality of what the original paper contained. The irony, of course, lies in our wanting to turn to analog sources of incomplete files to supply digitized texts for universal accessibility to texts.21 As Saunders has it:

Libraries should acknowledge that physical media, both microfilm and morgue, may well be irreplaceable historical resources and not merely ratty, old, or outdated junk . . . Creating a digital simulacrum is no adequate substitute for taking care of the original item.22

Special collections librarians should "know, and can express to other people, why it is so important to understand and maintain the relationship between content, context, and metadata, and what can happen to research and preservation when they are divorced from one another.”23 However, as special collections librarians must embrace the digital more and more, and seek out education and training in the relevant skills, they are moving further away from the research processes of their user communities. The special collections librarian approaches records for digital surrogates from the perspective of "organizational theory, functional analysis, complex systems, communications, and computer technology,” which are not necessarily the subject areas of their collections or their user communities. 24 In other words, as areas of study become more interdisciplinary, the digitization movement among special collections libraries is encouraging librarian specialization in organizational theories rather than in the theories and methods of the subjects covered by a collection. A librarian for a special collection related to American history should have expertise in that subject matter; yet, librarians are now seldom trained in subject areas to such a degree that they can fully engage with faculty and independent researchers in the field. 25 The connection between the researcher and the librarian is related to the connection that the researcher has to the physical institution in which the collection is housed, 26 and the loss or limiting of this connection as the Digital Age grows similarly reflects the limited connection that a researcher has to increasingly digitized materials.

In many ways, rare book and special collections librarians are caught between two extremes in making decisions about digitization. On one hand, traditional approaches to preservation, access, and research are adequate, familiar, and reliable. Even in the non-Western case, for example in Timbuktu, traditional disaster management and preservation techniques led to the safeguarding of most of the manuscripts held at major libraries in the city during the culturally destructive rebel assault of 2012-2013.27 In fact, it was those manuscripts exposed and vulnerable in the new, state-of-the-art, European-funded Ahmad Baba Institute restoration and digitization lab that were destroyed or damaged beyond repair.28 In the Timbuktu case, traditional techniques of storage and preservation (trunks and vaults; mud and stone mausoleums, libraries, and homes) and access (for scholarly and/or religious purposes only, in a physical building at the discretion of the librarian) were most effective for preserving and maintaining access to irreplaceable resources for scholars around the world. Many scholars who 
work closely with special collections would similarly claim that the traditional, physical interaction with materials is an essential and optimal research method.

On the other hand, digital surrogates limit the degradation of materials from human contact, and expand access by being readily available via the Internet, or at least by CD. It is perhaps most fruitful to try to view the tension among digitization, preservation, research methods, and access in the realm of special collections in a more positive light. As Blouin has said, special collections libraries-through their librarians-could "become a place of authority more than material, a place of meditation more than service, a place of community more than an institution, a place of connection more than repository." 29 Athena Jackson has similarly said that special collections librarians approach their reading rooms "without such intentionality" toward physical materials and access.30 Rather, the human-librarians and patrons alike-mediation of the digital, recalling the existence of the physical materials and requiring collaborative research methods, may be the way forward to safeguard the best aspects of the old (print) and the new (digital).

\section{Bionotes \\ Dale J. Correa}

Dale J. Correa is Head of the Global Studies Team and Middle Eastern Studies Librarian at the University of Texas at Austin, Perry-Castañeda Library. She is also a co-founder of the Endangered Libraries and Archives Committee of the Middle East Librarians Association, and currently leads an initiative through that group to record and recover written cultural heritage that has been lost during the conflict in Syria. In her research, Dr. Correa specializes in Islamic legal theory, theology, philosophy, and Qur'anic studies, with a particular interest in the intellectual tradition of the eastern regions of the Islamicate empire (namely, Transoxania, which is today in Uzbekistan/Tajikistan). Her current project examines the development and flourishing of the Transoxanian approach to testimony, or communication - that is, the transmission of knowledge of a past event by agents over time and space. 


\section{References}

1 Ofer Aderet, “As Israel State Archives Go Digital, Academics Fear Work Will Suffer,” Haaretz, April 11, 2016, accessed 10/5/2016, http://www.haaretz.com/israel-news/.premium-1.713943.

2 Aderet.

3 Yaacov Lozowick, "Letters on Israel: Response to Beth Baron and Amy Newhall,” Middle East Studies Association of North America, last modified July 20, 2016, http://mesana.org/committees/academic-

freedom/intervention/letters-israel.html\#Israel20160419_response.

4 Beth Baron and Amy Newhall, "Letters on Israel: Letter to Yaakov Lazovik, Naftali Bennet, and The Council for Higher Education of Israel,” Middle East Studies Association of North America, last modified July 20, 2016, http://mesana.org/committees/academic-freedom/intervention/letters-israel.html\#Israel20160419.

5 Akevot Institute, "Israel State Archives End Access to Paper Records; Archive Users Protest the Move,"

Akevot, last modified October 12, 2016, http://akevot.org.il/en/news-item/state-archive-ends-access-to-paper/. 6 Ferenc Földesi, "Digitizing the Corvinas: A Cooperative Project of the National Szechenyi Library of

Hungary,” RBM: A Journal of Rare Books, Manuscripts, and Cultural Heritage 6.1 (2005): 52.

7 Földesi, 52.

8 Földesi, 56.

9 Földesi, 53.

10 Beth M. Whittaker and Lynne M. Thomas, Special Collections 2.0: New Technologies for Rare Books, Manuscripts, and Archival Collections (Santa Barbara: Libraries Unlimited, 2009), p. 106.

11 Whittaker and Thomas, 106.

12 Földesi, 54.

13 Földesi, 56.

14 Földesi, 56.

15 Akevot Institute, "The Restriction of Public Access to Records in the Israel State Archives - Call to

Action,” Akevot, last modified April 30, 2016, http://akevot.org.il/wp-content/uploads/2016/04/2016-

417CalltoActionEng.pdf.

16 Akevot Institute.

17 Richard L. Saunders, “Too Late Now: Libraries’ Intertwined Challenges of Newspaper Morgues,

Microfilm, and Digitization,” RBM: A Journal of Rare Books, Manuscripts, and Cultural Heritage 15.2 (2015): 127. 18 Saunders, 129-30.

19 Saunders, 134-35.

20 Saunders, 134-35.

21 Saunders, 135.

22 Saunders, 139.

23 Whittaker and Thomas, 99-100.

24 Francis X. Blouin Jr., "Thoughts on Special Collections and Our Research Communities,” RBM: A

Journal of Rare Books, Manuscripts, and Cultural Heritage 11.1 (March 2010): 30.

25 Blouin, 30.

26 Blouin, 24.

27 Tombouctou Manuscripts Project, “Timbuktu Update,” Tombouctou Manuscripts Project, last modified

October 12, 2016, http://www.tombouctoumanuscripts.org/blog/entry/timbuktu_update/.

28 Tombouctou Manuscripts Project.

29 Blouin, 31.

30 Athena N. Jackson, "Forging into the Future: Facing Digital Realities and Forecasting Endeavors for

Special Collections Librarianship," in Forging the Future of Special Collections, ed. Melissa A. Hubbard, Robert H. Jackson, and Arnold Hirshon (Chicago: Neal-Schuman, 2016), p. 58.

Corresponding author: Dale J. Correa, University of Texas at Austin, Perry-Castañeda Library, 101 E. $21^{\text {st }}$ St., Austin, Texas 78712, United States. E-mail: d.correa@austin.utexas.edu 